\title{
Attitude of physical education teachers toward cooperative learning depending on the ownership and teaching experience
}

\author{
María Fernández-Rivas ${ }^{1}$ \\ ORCID: 0000-0002-3154-1606 \\ María Espada-Mateos² \\ ORCID: 0000-0002-3815-1037
}

\section{Abstract}

Cooperative tasks enhance learning, interaction and communication amongst students. Thus, this research aims to analyze the attitude of Physical Education teachers towards cooperative learning and possible improvements in different qualities in relation to ownership of the teaching center and teaching experience. The sample was made up of 455 Physical Education teachers (70.8\% men and 29.2\% women, aged from 30 to 50), and an inferential statistical analysis was carried out using different tests (ANOVA and Welch). The results of this investigation show that the attitude of the teachers who work in state schools is more positive than those working in semi-private schools as regards improvement of responsibility $(p=.002)$ and group discussion $(p=.000)$. Additionally, teachers who teach in state schools consider that cooperative learning improves group communications $(p=.000)$ and group cohesion $(p=.001)$ to a greater extent than teachers who work in semi-private and private schools. Moreover, the teachers with less teaching experience have a more positive attitude towards cooperative learning than the teachers who have more teaching experience, because the former consider that this method improves different skills in the students, such as socialization and social interaction, the acquisition of habits of coexistence, responsibility and co-responsibility, interpersonal relationships, group discussion, etc.

\section{Keywords}

Cooperative learning - Physical education - Ownership - Attitude - Teaching experience.

1- Universidad Pontificia de Comillas. Facultad de Ciencias Humanas y Sociales, Calle Universidad Comillas, Madrid, Spain. Contact: mfrivas@comillas.edu.

2- Universidad Politécnica de Madrid. Facultad de Ciencias de la Actividad Física y del Deporte, Madrid, Spain. 


\section{A postura dos professores de Educação Física em relação ao trabalho cooperativo e à centralidade do aluno na experiência de aprendizagem}

\section{Resumo}

O trabalho cooperativo propicia uma melhora na aprendizagem, na interação e na comunicação entre os estudantes. Portanto, o objetivo desta pesquisa é analisar a postura dos professores de Educação Física em relação à aprendizagem cooperativa a fim de aprimorar as experiências de ensino cuja centralidade esteja no aluno. Nossa amostra inclui 455 professores de Educação Física (70,8\% homens, 29,2\% mulheres, cuja idade varia de 30 a 50). Foi realizada uma análise estatística inferencial, com o uso de testes distintos (ANOVA e Welch). Os resultados desta pesquisa mostram que a postura dos professores de escolas públicas é mais positiva do que a dos professores de escolas semiprivadas no que se refere ao aumento da responsabilidade $(p=.002)$ e aos debates em grupo. Além disso, os professores de escolas públicas consideram que a aprendizagem cooperativa em seu ambiente de trabalho traz mais benefícios à comunicação em grupo $(p=.000)$ e à coesão do trabalho grupal $(p=.001)$ do que no ambiente de trabalho das escolas semi-privadas e privadas. Constatou-se, também, que os professores com menos experiência docente têm uma postura mais positiva em relação à aprendizagem cooperativa do que seus colegas mais experientes, pois os primeiros consideram que este método contribui para o desenvolvimento de uma série de habilidades dos alunos, tais como a interação social, o desenvolvimento de hábitos de convivência, responsabilidade e corresponsabilidade, melhores relações interpessoais, debates em grupo etc.

\section{Palavras-chave}

Aprendizagem cooperativa - Educação física - Centralidade - Postura - Experiência docente.

\section{Introduction}

Cooperative learning is defined by Johnson and Johnson (1991) as the use of working with different classmates taking full advantage of learning and interaction, and where the final objective cannot be achieved unless each student attains their own goal. Kagan (1994) defines cooperative learning as a way of working where there is interaction among the students on a proposed topic. This author indicates the difference between working in a group and cooperative learning, because in the former all the members do not have to work equally, while in cooperative learning all of them have to work equally to achieve the final aim. 
Learning can be carried out using two pedagogical models. One of them is teachercentered learning and the other is student-centered learning. So, cooperative learning is included within student-centered pedagogical models (WALLHEAD; DYSON, 2016). Some evidence claims that this type of pedagogical models contributes in a positive way to students, because it improves their engagement as it is centered on the learning process (GUERRA; HELENA, 2017; PERLMAN, 2015).

There are also different learning environments, that is, differing ways in which interactions occur in the classroom. On the one hand, different authors (JOHNSON; JOHNSON 1991; PRIETO, 2007) refer to situations of cooperative learning, where what is sought is the fulfillment of the group objectives, not the individual objective of each member, focusing on the benefit of the group at all times. On the other hand, the competitive learning situation seeks to achieve the best results, either individually or in a group, so that the other groups will have a poorer performance or lower score, thereby achieving the objective when the others do not achieve it or take longer to achieve it. Finally, there is the individualistic learning situation, where the students only think about their own work and the objective, without influencing the achievements of others.

Regarding some research on cooperative learning, Saborit et al. (2016) claim that teachers have a positive attitude toward cooperative learning after continuing education; they also claim that teachers consider this continuing education more useful than their initial training. In addition, an inverse correlation can be observed between the teachers' ages and their perception of cooperative learning.

Teweldebrhan (2015) claims in his research that students have a positive attitude toward learning when they are in a cooperative environment. Likewise, Johnson and Johnson (1996) show that cooperative learning is going to help students to develop social and interaction skills, as well as to promote relationships among students and favor the success of each student and the whole class. In addition, cooperative learning helps teachers to control the class with regard to organization, channels of communication, etc.

Although Gillies and Boyle (2010) and Blatchford, Kutnick, Baines, and Galton (2003) concluded in their research that in spite of the fact that teachers have a positive attitude toward cooperative learning, they reported having found difficulties when it was carried out.

More specifically, in the subject of Physical Education, some researchers claim the efficacy of cooperative learning in Physical Education with student-centered pedagogical models because these favor student engagement and positive interactions among students. Also, they suggest that if cooperative learning is used in Physical Education, these interactions could favor physical, cognitive, social and affective outcomes (DYSON; CASEY, 2012).

For these reasons, it was considered essential to know the teachers' attitude toward cooperative learning, given that this method is a strategy to improve students' development. In this way, once this attitude is revealed, it will be possible to assess 
how to influence teachers to implement the cooperative learning method in Physical Education classes.

\section{Method}

This research used a quantitative, descriptive and non-experimental methodology analyzing the collected data to verify the correlation among the objectively studied variables (ANGUERA, 1992; CEA D'ANCONA, 2001; GONZÁLEZ TIRADOS, 2009).

\section{Objectives}

The main objectives set out in this research were:

- To analyze the attitude of Physical Education teachers towards using cooperative learning in their classes based on school ownership.

- To analyze the attitude of Physical Education teachers towards using cooperative learning in their classes based on teaching experience.

\section{Sample}

This research used a sample of 455 teachers (70.8\% men and 29.2\% women), aged from 30 to 50. Out of these, 280 teachers (61.5\%) worked in primary education and 175 (38.5\%) in secondary education, with the following distribution: $51.4 \%$ working in state schools, 38.7\% in semi-private and 9.9\% in private schools.

It should be pointed out that teachers who work in state schools in Spain have previously passed a public examination, implying that they have had continued training up to when they have become teachers.

In addition, teaching experience was different, as the sample included teachers with from 1 to $5(40 \%)$, from 6 to $10(30.3 \%)$, from 11 to $15(16 \%)$, from 16 to $20(6.8 \%)$ and more than $21(6.8 \%)$ years of experience.

To calculate the sample universe, the number of schools in the Autonomous Region of Madrid was determined from the different lists of educational institutions in this region, as it was impossible to know the exact number of teachers who work in these schools. The lists used were those of primary and secondary schools in the region detailed in the Regional Guide to schools (AUTONOMOUS..., 2014) and the list of municipalities and population in the same region for the year 2013 (INSTITUTE..., 2013), totaling 1659 schools.

The size of the sample was determined using the formula for finite populations (CEA D'ANCONA, 2004), where the worst case is assumed regarding the population variance, with "P" and "Q" being equal, with a value of 50\% each. The value of confidence was 95.5\% with - 2 sigmas and +2 sigmas for a normal distribution, and a margin of error of $\pm 4.75 \%$ for the established sample, obtaining a sample of 455 units in the population. 
The sample design was probabilistic, random cluster and stratified to obtain a more objective selection. The stratification consisted of dividing the population, at first, into municipalities; later, into schools, then randomly selecting the participating schools, and finally the teachers to be interviewed (maximum two teachers per school) using the table of random numbers, proposed by Rodríguez Osuna (2002).

The data collection was therefore always proportional, in the established criteria, to municipal population size and geographic area, according to the defined territorial areas of the total universe, taking into account the number of inhabitants per municipality. Therefore, -a larger number of surveys was carried out in strata with more inhabitants (CEA D'ANCONA, 2001).

\section{Instrument}

The instrument used is referred to by some authors as a standardized interview with a questionnaire (HEINEMANN, 2003) or a structured interview (Lussier \& Kimball, 2008). In this case, we used a questionnaire on cooperative work, called the scalequestionnaire of the attitude of the teaching staff towards educational innovation by means of cooperative working (CAPIC), which was created by Traver and García (2007) and presented a coefficient of reliability of $\alpha=.9381$, and a rate of homogeneity of (ri(t-i)) $>0.5$, thus increasing the consistency of the questionnaire.

\section{Procedure}

During the first phase the location, contact schools and teachers were selected for the study, following the guidelines established in the sample design. Then, a standardized interview was carried out with the questionnaire and the information obtained was collected and recorded.

This was a cross-sectional study which took place during the 2014-2015 academic year during school hours, since it was aimed at Physical Education teachers in formal education.

The statistical analysis was descriptive using frequencies, and an inferential analysis through correlation coefficients (ANOVA and Welch), using the statistical program SPSS ${ }^{\circledR}$, Version 20.

\section{Results}

With regard to the differences in means (M) and the standard deviation (SD) in two of the items, they turned out to be higher. In the first one, when it was asked whether cooperative work improves interpersonal relations $(\mathrm{M}=4.556 ; \mathrm{SD}=0.73)$; in the second item, whether cooperative work allows the development of interaction skills among students $(\mathrm{M}=4.5582$; $\mathrm{SD}=0.757)$.

The Levene test on the items as a function of school ownership revealed that half of them showed significant differences $(\mathrm{p}<.05)$ referring to whether cooperative 
work improves interpersonal relationships (item 1), abilities for social interaction (item 2), group discussion (item 7), understanding towards others (item 8), habits of coexistence (item 9), socialization (item 10), learning from each other (item 12), the responsibility of the student for the task (item 14) and communication among students (item 18).

In these cases, the Welch test was applied to check where significant differences could be found. Thus, this test showed that items 1 ( $p=.01), 2(p=.048), 7$ ( $p=.003)$, $8(\mathrm{p}=.003), 9(\mathrm{p}=.021), 14(\mathrm{p}=.003)$ and $18(\mathrm{p}=.000)$ are statistically significant $(p<.05)$. To see where those differences were in greater detail we used the GamesHowell post hoc test (Table 1), which showed that there were significant differences between semi-private and state schools, with a more positive attitude in state schools in item 1, about whether cooperative work improves interpersonal relationships (p $=.009$ ); item 2, about whether cooperative learning improves social interaction skills ( $\mathrm{p}=.035)$; item 7 , about whether cooperative learning improves group discussion ( $p$ $=.002$ ) ; item 9, about whether cooperative learning improves the habits of coexistence ( $\mathrm{p}=.015)$; and item 14, about whether cooperative learning improves responsibility for the students' tasks ( $\mathrm{p}=.002)$. Also, significant differences were revealed between public and semi-private schools $(\mathrm{p}=.005)$ and semi-private and private schools ( $\mathrm{p}$ $=.02$ ) in item 8 about whether cooperative learning improves understanding of others, with teachers who work in state or private schools showing a more positive attitude about this item than teachers who work in semi-private schools. Finally, the question of whether cooperative learning promotes communication among students (item 18) shows a significant difference $(\mathrm{p}=.000)$ between semi-private schools and private and state schools, with teachers from state schools supporting this claim in contrast to teachers from semi-private and private schools.

For the items in which there were not significant differences in the Levene test of homogeneity, we applied the coefficient of correlation, ANOVA, which showed significant differences $(\mathrm{p}<.05)$ in item number 13 , about whether cooperative work improves awareness of students with disabilities ( $\mathrm{p}=.023)$; in item 15, about whether cooperative learning encourages co-responsibility ( $p=.01)$; in item 16 , about whether cooperative learning enables positive individual assessments $(\mathrm{p}=.008)$; and in item 17, about whether cooperative learning improves the performance of students with special educational needs $(p=.023)$. After this, Tukey's post hoc test was applied to discover which categories revealed these differences (Table 2). Differences were found between semi-private schools and state schools, where the latter have a more positive attitude towards cooperative work on items 13, 15, 16 and 17. Also in item 19 about whether cooperative work makes the group more united, significant differences were revealed by Tukey's post hoc test between state and semi-private and private schools, with the state schools showing greater support for this statement about cooperative work than the semi-private or private schools $(\mathrm{p}=.001)$. 
Table 1- Games-Howell post hoc test regarding ownership

\begin{tabular}{|c|c|c|c|c|c|}
\hline Items & (I) Ownership & (J) Ownership & Mean difference (I-J) & Typical error & Sig. \\
\hline \multirow{6}{*}{$\begin{array}{l}\text { 1. Cooperative work will improve relationships } \\
\text { among students }\end{array}$} & \multirow{2}{*}{ State } & Semi-private & $.21494^{*}$ & 0.07226 & 0.009 \\
\hline & & Private & 0.19145 & 0.12938 & 0.308 \\
\hline & \multirow{2}{*}{ Semi-private } & State & $-.21494^{*}$ & 0.07226 & 0.009 \\
\hline & & Private & -0.02348 & 0.13407 & 0.983 \\
\hline & \multirow{2}{*}{ Private } & State & -0.19145 & 0.12938 & 0.308 \\
\hline & & Semi-private & 0.02348 & 0.13407 & 0.983 \\
\hline \multirow{6}{*}{$\begin{array}{l}\text { 2. Cooperative learning will develop social } \\
\text { interaction skills }\end{array}$} & \multirow{2}{*}{ State } & Semi-private & $.19784^{*}$ & 0.07921 & 0.035 \\
\hline & & Private & 0.06325 & 0.10255 & 0.811 \\
\hline & \multirow{2}{*}{ Semi-private } & State & $-.19784^{*}$ & 0.07921 & 0.035 \\
\hline & & Private & -0.1346 & 0.11361 & 0.465 \\
\hline & \multirow{2}{*}{ Private } & State & -0.06325 & 0.10255 & 0.811 \\
\hline & & Semi-private & 0.1346 & 0.11361 & 0.465 \\
\hline \multirow{6}{*}{$\begin{array}{l}\text { 7. Cooperative learning will encourage tack and } \\
\text { group discussion }\end{array}$} & \multirow{2}{*}{ State } & Semi-private & $.34207^{\star}$ & 0.09803 & 0.002 \\
\hline & & Private & 0.12137 & 0.12825 & 0.613 \\
\hline & \multirow{2}{*}{ Semi-private } & State & $-.34207^{*}$ & 0.09803 & 0.002 \\
\hline & & Private & -0.22071 & 0.14381 & 0.279 \\
\hline & \multirow{2}{*}{ Private } & State & -0.12137 & 0.12825 & 0.613 \\
\hline & & Semi-private & 0.22071 & 0.14381 & 0.279 \\
\hline \multirow{6}{*}{$\begin{array}{c}\text { 8. Cooperative learning will allow students to put } \\
\text { themselves in the place of others and enhance } \\
\text { understanding }\end{array}$} & \multirow{2}{*}{ State } & Semi-private & $.29235^{\star}$ & 0.09259 & 0.005 \\
\hline & & Private & -0.10513 & 0.13058 & 0.701 \\
\hline & \multirow{2}{*}{ Semi-private } & State & $-0.29235^{\star}$ & 0.09259 & 0.005 \\
\hline & & Private & $-0.39747^{*}$ & 0.14512 & 0.02 \\
\hline & \multirow{2}{*}{ Private } & State & 0.10513 & 0.13058 & 0.701 \\
\hline & & Semi-private & $0.39747^{\star}$ & 0.14512 & 0.02 \\
\hline \multirow{6}{*}{$\begin{array}{l}\text { 9. Cooperative learning will favor the acquisition of } \\
\text { habits of coexistence }\end{array}$} & \multirow{2}{*}{ State } & Semi-private & $0.21188^{*}$ & 0.07554 & 0.015 \\
\hline & & Private & 0.02564 & 0.09701 & 0.962 \\
\hline & \multirow{2}{*}{ Semi-private } & State & $-0.21188^{*}$ & 0.07554 & 0.015 \\
\hline & & Private & -0.18624 & 0.10752 & 0.199 \\
\hline & \multirow{2}{*}{ Private } & State & -0.02564 & 0.09701 & 0.962 \\
\hline & & Semi-private & 0.18624 & 0.10752 & 0.199 \\
\hline \multirow{6}{*}{$\begin{array}{l}\text { 14. Cooperative learning will help making the } \\
\text { student feel more responsible for tasks }\end{array}$} & \multirow{2}{*}{ State } & Semi-private & $0.32338^{*}$ & 0.094 & 0.002 \\
\hline & & Private & 0.01795 & 0.12073 & 0.988 \\
\hline & \multirow{2}{*}{ Semi-private } & State & $-0.32338^{*}$ & 0.094 & 0.002 \\
\hline & & Private & -0.30543 & 0.1347 & 0.065 \\
\hline & \multirow{2}{*}{ Private } & State & -0.01795 & 0.12073 & 0.988 \\
\hline & & Semi-private & 0.30543 & 0.1347 & 0.065 \\
\hline \multirow{6}{*}{$\begin{array}{l}\text { 18. Cooperative learning will enhance } \\
\text { communication among them }\end{array}$} & State & Semi-private & $0.247^{*}$ & 0.089 & 0.016 \\
\hline & slate & Private & $0.674^{\star}$ & 0.195 & 0.003 \\
\hline & Sominniveto & State & $-0.247^{*}$ & 0.089 & 0.016 \\
\hline & Selmilprivale & Private & 0.427 & 0.2 & 0.091 \\
\hline & Privato & State & $-0.674^{*}$ & 0.195 & 0.003 \\
\hline & PIIVale & Semi-private & -0.427 & 0.2 & 0.091 \\
\hline
\end{tabular}

Source: own processing. 
Table 2- Tukey's post - hoc test in relation to ownership

\begin{tabular}{|c|c|c|c|c|c|}
\hline Items & (I) Ownership & (J) Ownership & Mean difference (I-J) & Typical error & Sig. \\
\hline \multirow{6}{*}{$\begin{array}{l}\text { 13. Cooperative learning will increase sensitivity } \\
\text { towards classmates with difficulties or problems }\end{array}$} & \multirow{2}{*}{ State } & Semi-private & 21256. * & 0.08363 & 0.03 \\
\hline & & Private & 0.23162 & 0.13644 & 0.207 \\
\hline & \multirow{2}{*}{ Semi-private } & State & $-21256 . *$ & 0.08363 & 0.03 \\
\hline & & Private & 0.01907 & 0.14001 & 0.99 \\
\hline & \multirow{2}{*}{ Private } & State & -0.23162 & 0.13644 & 0.207 \\
\hline & & Semi-private & -0.01907 & 0.14001 & 0.99 \\
\hline \multirow{6}{*}{$\begin{array}{l}\text { 15. Cooperative learning will stimulate } \\
\text { co-responsibility }\end{array}$} & \multirow{2}{*}{ State } & Semi-private & $24247^{*}$ & 0.08072 & 0.008 \\
\hline & & Private & 0.03932 & 0.13169 & 0.952 \\
\hline & \multirow{2}{*}{ Semi-private } & State & $-24247 . *$ & 0.08072 & 0.008 \\
\hline & & Private & -0.20316 & 0.13515 & 0.29 \\
\hline & \multirow{2}{*}{ Private } & State & -0.03932 & 0.13169 & 0.952 \\
\hline & & Semi-private & 0.20316 & 0.13515 & 0.29 \\
\hline \multirow{6}{*}{$\begin{array}{l}\text { 16. Cooperative learning will allow positive } \\
\text { individual assessments }\end{array}$} & \multirow{2}{*}{ State } & Semi-private & 22727. * & 0.07495 & 0.007 \\
\hline & & Private & 0.18889 & 0.12227 & 0.271 \\
\hline & \multirow{2}{*}{ Semi-private } & State & $-22727 . *$ & 0.07495 & 0.007 \\
\hline & & Private & -0.03838 & 0.12548 & 0.95 \\
\hline & \multirow{2}{*}{ Private } & State & -0.18889 & 0.12227 & 0.271 \\
\hline & & Semi-private & 0.03838 & 0.12548 & 0.95 \\
\hline \multirow{6}{*}{$\begin{array}{l}\text { 17. Cooperative learning will improve the } \\
\text { performance of students with special educational } \\
\text { needs }\end{array}$} & \multirow{2}{*}{ State } & Semi-private & $271^{*}$ & 0.099 & 0.018 \\
\hline & & Private & 0.072 & 0.161 & 0897 \\
\hline & \multirow{2}{*}{ Semi-private } & State & $-271 .{ }^{*}$ & 0.099 & 0.018 \\
\hline & & Private & -0.199 & 0.166 & 0.453 \\
\hline & \multirow{2}{*}{ Private } & State & -0.072 & 0.161 & 0897 \\
\hline & & Semi-private & 0.199 & 0.166 & 0.453 \\
\hline \multirow{6}{*}{$\begin{array}{l}\text { 19. Cooperative learning will promote greater } \\
\text { group cohesion }\end{array}$} & \multirow{2}{*}{ State } & Semi-private & 293 * & 0.099 & 0.009 \\
\hline & & Private & 501 * & 0.162 & 0.006 \\
\hline & \multirow{2}{*}{ Semi-private } & State & $-0.293^{*}$ & 0.099 & 0.009 \\
\hline & & Private & 0.208 & 0.166 & 0.424 \\
\hline & \multirow{2}{*}{ Private } & State & -0.501 * & 0.162 & 0.006 \\
\hline & & Semi-private & -0.208 & 0.166 & 0.424 \\
\hline
\end{tabular}

Source: own processing. 
Regarding teaching experience, the Levene test was carried out, and showed significant differences which relate to whether cooperative learning improves: interpersonal relationships (item 1), abilities for social interaction (item 2), integration of students with special educational needs (item 3), group enrichment through new ideas (item 6), group discussions (item 7), the students putting themselves in the place of others and enhancing their understanding (item 8), habits of coexistence (item 9), helping to recognize group diversity (item 11), being aware that all of them learn from one another (item 12), responsibility for the students' tasks (item 14), stimulation of co-responsibility (item 15) and communication enhancement among them (item 18) $(\mathrm{p}<.05)$.

Therefore, the Welch test was applied to check where there were significant differences, revealing that items $2(\mathrm{p}=.004), 6(\mathrm{p}=.005), 8(\mathrm{p}=.005), 9(\mathrm{p}=.001), 14$ $(\mathrm{p}=.001), 15(\mathrm{p}=.002)$ and $18(\mathrm{p}=.028)$ were statistically significant.

To see where those differences were in greater detail we used the GamesHowell post hoc test (Table 3), which showed that there were significant differences between teachers who have been teaching Physical Education for 1 to 15 years and teachers who have been teaching for more than 21 years regarding item 2 about whether cooperative learning improves social interaction skills (from 1 to $5, p=.011$; from 6 to 10, $\mathrm{p}=.009$; from 11 to $15, \mathrm{p}=.014$; from 16 to 20, $\mathrm{p}=.035$ ) and item 9 , about whether cooperative learning improves habits of coexistence (from 1 to 5 , $\mathrm{p}=.005$; from 6 to $10, \mathrm{p}=.011$; from 11 to $15, \mathrm{p}=.004$ ), with the younger teachers having a more positive attitude.

Also, for item 6, about whether cooperative learning will enrich the group through new ideas, the teachers having from 6 to $10(p=.014)$ and from 11 to 15 $(p=.045)$ years of experience have a more positive attitude to cooperative learning than teachers with more than 21 years of experience. Finally, for item 14, about whether cooperative learning improves responsibility for the students' tasks (from 1 to $5, \mathrm{p}=.002$; from 6 to $10, \mathrm{p}=.001$; from 11 to $15, \mathrm{p}=.021$ ), and for item 15 , about whether cooperative learning will stimulate co-responsibility, teachers who have from 1 to 20 years of experience (from 1 to $5, \mathrm{p}=.001$; from 6 to 10, $\mathrm{p}=.003$; from 11 to $15, \mathrm{p}=.003$; from 16 to $20, \mathrm{p}=.01$ ) had a more positive attitude towards cooperative learning than teachers with more than 21 years of experience.

In addition, for the items in which there were not significant differences in the Levene test of homogeneity, we applied the coefficient of correlation, ANOVA, which showed significant differences $(\mathrm{p}<.05)$ in item 4 , about whether cooperative learning improves the students' tendency to help each other $(p=.003), 10$, about whether cooperative learning improves socialization among students $(p=.007)$, in item 17 , about whether cooperative learning will improve the performance of students with special educational needs $(\mathrm{p}=.04)$ and in item 19, about whether cooperative learning will promote more group cohesion $(p=.018)$. 
Table 3- Games-Howell post hoc test regarding teachers' experience

\begin{tabular}{|c|c|c|c|c|c|}
\hline & (I) Teachers' experience & (J) Teachers' experience & Mean difference (I-J) & Typical error & Sig. \\
\hline \multirow{12}{*}{$\begin{array}{l}\text { 6. Cooperative learning } \\
\text { will enrich the group } \\
\text { through new ideas }\end{array}$} & \multirow{4}{*}{ from 11 to 15} & from 1 to 5 & 0.06458 & 0.10872 & 0.976 \\
\hline & & from 6 to 10 & -0.08656 & 0.10579 & 0.925 \\
\hline & & from 16 to 20 & 0.23509 & 0.18378 & 0.705 \\
\hline & & More than 21 & $.68670^{*}$ & 0.23717 & 0.045 \\
\hline & \multirow{4}{*}{ from 16 to 20} & from 1 to 5 & -0.17051 & 0.17181 & 0.857 \\
\hline & & from 6 to 10 & -0.32165 & 0.16997 & 0.339 \\
\hline & & from 11 to 15 & -0.23509 & 0.18378 & 0.705 \\
\hline & & More than 21 & 0.45161 & 0.27194 & 0.466 \\
\hline & \multirow{4}{*}{ More than 21} & from 1 to 5 & -0.62212 & 0.22802 & 0.07 \\
\hline & & from 6 to 10 & $-.77326^{\star}$ & 0.22664 & 0.014 \\
\hline & & from 11 to 15 & $-.68670^{*}$ & 0.23717 & 0.045 \\
\hline & & from 16 to 20 & -0.45161 & 0.27194 & 0.466 \\
\hline \multirow{20}{*}{$\begin{array}{l}\text { 9. Cooperative learning } \\
\text { improves the habits of } \\
\text { coexistence }\end{array}$} & \multirow{4}{*}{ from 1 to 5} & from 6 to 10 & 0.05343 & 0.0732 & 0.949 \\
\hline & & from 11 to 15 & -0.04772 & 0.09097 & 0.985 \\
\hline & & from 16 to 20 & 0.35661 & 0.13768 & 0.092 \\
\hline & & More than 21 & $.77597^{\star}$ & 0.20491 & 0.005 \\
\hline & \multirow{4}{*}{ from 6 to 10} & from 1 to 5 & -0.05343 & 0.0732 & 0.949 \\
\hline & & from 11 to 15 & -0.10115 & 0.09425 & 0.82 \\
\hline & & from 16 to 20 & 0.30318 & 0.13987 & 0.212 \\
\hline & & More than 21 & $.72253^{*}$ & 0.20638 & 0.011 \\
\hline & \multirow{4}{*}{ from 11 to 15} & from 1 to 5 & 0.04772 & 0.09097 & 0.985 \\
\hline & & from 6 to 10 & 0.10115 & 0.09425 & 0.82 \\
\hline & & from 16 to 20 & 0.40433 & 0.14994 & 0.068 \\
\hline & & More than 21 & $.82369^{\star}$ & 0.21334 & 0.004 \\
\hline & \multirow{4}{*}{ from 16 to 20} & from 1 to 5 & -0.35661 & 0.13768 & 0.092 \\
\hline & & from 6 to 10 & -0.30318 & 0.13987 & 0.212 \\
\hline & & from 11 to 15 & -0.40433 & 0.14994 & 0.068 \\
\hline & & More than 21 & 0.41935 & 0.23705 & 0.402 \\
\hline & \multirow{4}{*}{ More than 21} & from 1 to 5 & $-.77597^{\star}$ & 0.20491 & 0.005 \\
\hline & & from 6 to 10 & $-.72253^{*}$ & 0.20638 & 0.011 \\
\hline & & from 11 to 15 & $-.82369^{\star}$ & 0.21334 & 0.004 \\
\hline & & from 16 to 20 & -0.41935 & 0.23705 & 0.402 \\
\hline \multirow{20}{*}{$\begin{array}{l}\text { 14. Cooperative learning } \\
\text { improves responsibility for } \\
\text { the students' tasks }\end{array}$} & \multirow{4}{*}{ from 1 to 5} & from 6 to 10 & -0.03488 & 0.0907 & 0.995 \\
\hline & & from 11 to 15 & 0.16792 & 0.1266 & 0.675 \\
\hline & & from 16 to 20 & 0.12992 & 0.17899 & 0.949 \\
\hline & & More than 21 & $.93637^{*}$ & 0.22408 & 0.002 \\
\hline & \multirow{4}{*}{ from 6 to 10} & from 1 to 5 & 0.03488 & 0.0907 & 0.995 \\
\hline & & from 11 to 15 & 0.2028 & 0.12849 & 0.514 \\
\hline & & from 16 to 20 & 0.1648 & 0.18033 & 0.89 \\
\hline & & More than 21 & $.97125^{\star}$ & 0.22516 & 0.001 \\
\hline & \multirow{4}{*}{ from 11 to 15} & from 1 to 5 & -0.16792 & 0.1266 & 0.675 \\
\hline & & from 6 to 10 & -0.2028 & 0.12849 & 0.514 \\
\hline & & from 16 to 20 & -0.038 & 0.2008 & 1 \\
\hline & & More than 21 & $.76845^{\star}$ & 0.24186 & 0.021 \\
\hline & \multirow{4}{*}{ from 16 to 20} & from 1 to 5 & -0.12992 & 0.17899 & 0.949 \\
\hline & & from 6 to 10 & -0.1648 & 0.18033 & 0.89 \\
\hline & & from 11 to 15 & 0.038 & 0.2008 & 1 \\
\hline & & More than 21 & $.80645^{\star}$ & 0.27296 & 0.035 \\
\hline & \multirow{4}{*}{ More than 21} & from 1 to 5 & $-.93637^{*}$ & 0.22408 & 0.002 \\
\hline & & from 6 to 10 & $-.97125^{\star}$ & 0.22516 & 0.001 \\
\hline & & from 11 to 15 & $-.76845^{\star}$ & 0.24186 & 0.021 \\
\hline & & from 16 to 20 & $-.80645^{\star}$ & 0.27296 & 0.035 \\
\hline
\end{tabular}


Attitude of physical education teachers toward cooperative learning depending on the ownership and teaching ...

\begin{tabular}{|c|c|c|c|c|c|}
\hline \multirow{20}{*}{$\begin{array}{l}\text { 15. Cooperative } \\
\text { learning will stimulate } \\
\text { co-responsibility }\end{array}$} & \multirow{4}{*}{ from 1 to 5} & from 6 to 10 & 0.03607 & 0.09067 & 0.995 \\
\hline & & from 11 to 15 & 0.01731 & 0.10695 & 1 \\
\hline & & from 16 to 20 & 0.02836 & 0.13798 & 1 \\
\hline & & More than 21 & $.73804^{*}$ & 0.17618 & 0.001 \\
\hline & \multirow{4}{*}{ from 6 to 10} & from 1 to 5 & -0.03607 & 0.09067 & 0.995 \\
\hline & & from 11 to 15 & -0.01876 & 0.11191 & 1 \\
\hline & & from 16 to 20 & -0.00771 & 0.14186 & 1 \\
\hline & & More than 21 & $.70196^{\star}$ & 0.17923 & 0.003 \\
\hline & \multirow{4}{*}{ from 11 to 15} & from 1 to 5 & -0.01731 & 0.10695 & 1 \\
\hline & & from 6 to 10 & 0.01876 & 0.11191 & 1 \\
\hline & & from 16 to 20 & 0.01105 & 0.15278 & 1 \\
\hline & & More than 21 & $.72072^{*}$ & 0.188 & 0.003 \\
\hline & \multirow{4}{*}{ from 16 to 20} & from 1 to 5 &,$- 73804^{*}$ & 0,17618 & 0,001 \\
\hline & & from 6 to 10 &,$- 70196^{\star}$ & 0,17923 & 0,003 \\
\hline & & from 11 to 15 &,$- 72072^{\star}$ & 0,188 & 0,003 \\
\hline & & More than 21 & $.70968^{\star}$ & 0.20722 & 0.01 \\
\hline & \multirow{4}{*}{ More than 21} & from 1 to 5 & $-.73804^{*}$ & 0.17618 & 0.001 \\
\hline & & from 6 to 10 & $-.70196^{\star}$ & 0.17923 & 0.003 \\
\hline & & from 11 to 15 & $-.72072^{*}$ & 0.188 & 0.003 \\
\hline & & from 16 to 20 & $-.70968^{*}$ & 0.20722 & 0.01 \\
\hline
\end{tabular}

Source: own processing.

After this, Tukey's post hoc test was applied to find out which categories revealed these differences (Table 4). Differences were found between teachers with from 1 to 15 years of experience compared to teachers with more than 21 years of experience, where the youngest have a more positive attitude towards cooperative work on item 4, about whether cooperative learning improves the students' tendency to help each other (from 1 to $5, \mathrm{p}=.013$; from 6 to $10, \mathrm{p}=.009$; from 11 to $15, \mathrm{p}=.048$ ). In item 10 , teachers who have from 6 to 10 years of experience have a more positive attitude towards cooperative learning to improve socialization among students than teachers who have from 16 to $20(\mathrm{p}=.047)$ and more than 21 years of experience $(\mathrm{p}=.047)$. Also in item 19, about whether cooperative learning will promote more group cohesion, significant differences were revealed by Tukey's post hoc test between teachers who have from 1 to 5 years of experience, showing greater support for this statement about cooperative work than those who have from 6 to 10 years of experience $(p=.047)$. 
Table 4- Tukey's post-hoc test in relation to teachers' experience

\begin{tabular}{|c|c|c|c|c|c|}
\hline & $\begin{array}{l}\text { (I) Teachers' } \\
\text { experience }\end{array}$ & $\begin{array}{l}\text { (J) Teachers' } \\
\text { experience }\end{array}$ & Mean difference (I-J) & Typical error & Sig. \\
\hline \multirow{20}{*}{$\begin{array}{l}\text { 4. Cooperative learning improves students' } \\
\text { tendency to help each other }\end{array}$} & \multirow{4}{*}{ from 1 to 5} & from 6 to 10 & -0.02922 & 0.09254 & 0.998 \\
\hline & & from 11 to 15 & 0.02597 & 0.11358 & 0.999 \\
\hline & & from 16 to 20 & 0.34899 & 0.15929 & 0.185 \\
\hline & & More than 21 & $.51028^{\star}$ & 0.15929 & 0.013 \\
\hline & \multirow{4}{*}{ from 6 to 10} & from 1 to 5 & 0.02922 & 0.09254 & 0.998 \\
\hline & & from 11 to 15 & 0.05519 & 0.11865 & 0.99 \\
\hline & & from 16 to 20 & 0.37821 & 0.16294 & 0.14 \\
\hline & & More than 21 & $.53950^{*}$ & 0.16294 & 0.009 \\
\hline & \multirow{4}{*}{ from 11 to 15} & from 1 to 5 & -0.02597 & 0.11358 & 0.999 \\
\hline & & from 6 to 10 & -0.05519 & 0.11865 & 0.99 \\
\hline & & from 16 to 20 & 0.32302 & 0.17575 & 0.353 \\
\hline & & More than 21 & $.48431^{*}$ & 0.17575 & 0.048 \\
\hline & \multirow{4}{*}{ from 16 to 20} & from 1 to 5 & -0.34899 & 0.15929 & 0.185 \\
\hline & & from 6 to 10 & -0.37821 & 0.16294 & 0.14 \\
\hline & & from 11 to 15 & -0.32302 & 0.17575 & 0.353 \\
\hline & & More than 21 & 0.16129 & 0.20823 & 0.938 \\
\hline & \multirow{4}{*}{ More than 21} & from 1 to 5 & $-.51028^{*}$ & 0.15929 & 0.013 \\
\hline & & from 6 to 10 & $-.53950^{*}$ & 0.16294 & 0.009 \\
\hline & & from 11 to 15 & $-.48431^{\star}$ & 0.17575 & 0.048 \\
\hline & & from 16 to 20 & -0.16129 & 0.20823 & 0.938 \\
\hline \multirow{20}{*}{$\begin{array}{l}\text { 10. Cooperative learning improves socialization } \\
\text { among students }\end{array}$} & \multirow{4}{*}{ from 1 to 5} & from 6 to 10 & -0.04475 & 0.08243 & 0.983 \\
\hline & & from 11 to 15 & -0.01219 & 0.10117 & 1 \\
\hline & & from 16 to 20 & 0.3559 & 0.14189 & 0.091 \\
\hline & & More than 21 & 0.3559 & 0.14189 & 0.091 \\
\hline & \multirow{4}{*}{ from 6 to 10} & from 1 to 5 & 0.04475 & 0.08243 & 0.983 \\
\hline & & from 11 to 15 & 0.03256 & 0.10569 & 0.998 \\
\hline & & from 16 to 20 & $.40065^{\star}$ & 0.14515 & 0.047 \\
\hline & & More than 21 & $.40065^{\star}$ & 0.14515 & 0.047 \\
\hline & \multirow{4}{*}{ from 11 to 15} & from 1 to 5 & 0.01219 & 0.10117 & 1 \\
\hline & & from 6 to 10 & -0.03256 & 0.10569 & 0.998 \\
\hline & & from 16 to 20 & 0.3681 & 0.15655 & 0.131 \\
\hline & & More than 21 & 0.3681 & 0.15655 & 0.131 \\
\hline & \multirow{4}{*}{ from 16 to 20} & from 1 to 5 & -0.3559 & 0.14189 & 0.091 \\
\hline & & from 6 to 10 & $-.40065^{\star}$ & 0.14515 & 0.047 \\
\hline & & from 11 to 15 & -0.3681 & 0.15655 & 0.131 \\
\hline & & More than 21 & 0 & 0.18549 & 1 \\
\hline & \multirow{4}{*}{ More than 21} & from 1 to 5 & -0.3559 & 0.14189 & 0.091 \\
\hline & & from 6 to 10 & $-.40065^{\star}$ & 0.14515 & 0.047 \\
\hline & & from 11 to 15 & -0.3681 & 0.15655 & 0.131 \\
\hline & & from 16 to 20 & 0 & 0.18549 & 1 \\
\hline
\end{tabular}




\begin{tabular}{|c|c|c|c|c|c|}
\hline \multirow{20}{*}{$\begin{array}{l}\text { 19. Cooperative learning will promote greater group } \\
\text { cohesion }\end{array}$} & \multirow{4}{*}{ from 1 to 5} & from 6 to 10 & $.311^{*}$ & 0.113 & 0.047 \\
\hline & & from 11 to 15 & 0.069 & 0.139 & 0.988 \\
\hline & & from 16 to 20 & 0.234 & 0.194 & 0.748 \\
\hline & & More than 21 & 0.492 & 0.194 & 0.085 \\
\hline & \multirow{4}{*}{ from 6 to 10} & from 1 to 5 & $-.311^{*}$ & 0.113 & 0.047 \\
\hline & & from 11 to 15 & -0.242 & 0.145 & 0.45 \\
\hline & & from 16 to 20 & -0.077 & 0.199 & 0.995 \\
\hline & & More than 21 & 0.181 & 0.199 & 0.893 \\
\hline & \multirow{4}{*}{ from 11 to 15} & from 1 to 5 & -0.069 & 0.139 & 0.988 \\
\hline & & from 6 to 10 & 0.242 & 0.145 & 0.45 \\
\hline & & from 16 to 20 & 0.165 & 0.214 & 0.939 \\
\hline & & More than 21 & 0.423 & 0.214 & 0.28 \\
\hline & \multirow{4}{*}{ from 16 to 20} & from 1 to 5 & -0.234 & 0.194 & 0.748 \\
\hline & & from 6 to 10 & 0.077 & 0.199 & 0.995 \\
\hline & & from 11 to 15 & -0.165 & 0.214 & 0.939 \\
\hline & & More than 21 & 0.258 & 0.254 & 0.848 \\
\hline & \multirow{4}{*}{ More than 21} & from 1 to 5 & -0.492 & 0.194 & 0.085 \\
\hline & & from 6 to 10 & -0.181 & 0.199 & 0.893 \\
\hline & & from 11 to 15 & -0.423 & 0.214 & 0.28 \\
\hline & & from 16 to 20 & -0.258 & 0.254 & 0.848 \\
\hline
\end{tabular}

Source: own processing.

\section{Discussion and conclusion}

An analysis of the data collected reveals that teachers have different attitudes towards cooperative work as a function of ownership of the school where they teach. Eroglu and Unlu (2015) claim that Physical Education teachers' attitude toward their teaching profession is positive and that "they chose the Physical Education teaching profession knowingly and willfully". In addition, it is possible to claim that physical activity, and therefore, physical education linked to cooperative learning allow "the academic achievement of lower achieving children" (SHOVAL; SHULRUF, 2011).

In this way, this investigation shows, first of all, that teachers in state schools have a more positive attitude towards cooperative learning than teachers in semi-private schools. The positive attitude toward cooperative learning in the Physical Education class results from the belief that cooperative learning brings benefits to students, such as improvement in interpersonal relationships, social interaction, positive individual assessments, the tack and the group discussion, habits of coexistence, responsibility and co-responsibility in students towards tasks and some improvement in the performance of students with special educational needs, as well as awareness in the other students about these needs.

Secondly, it was shown that teachers in state and private schools have a more positive attitude towards cooperative learning regarding improvement of the understanding of the students towards each other, in contrast to teachers who work in semi-private schools. 
Finally, regarding ownership, the teachers of state schools have a more positive attitude towards cooperative learning regarding whether it facilitates communication among them, which will cause the group to be brought together, in contrast to teachers from both semi-private and private schools.

This significant difference between teachers' attitude according to ownership has not been investigated up to now, although there is a lot of research which shows that teachers have a positive attitude toward cooperative learning because they consider there is an improvement in the students, mainly in the interaction among them and in helping students with special educational needs (SHOVAL; SHULRUF, 2011). Also, André, Deneuve, and Louvet (2011) claim that cooperative work allows students to positively appreciate classmates with limited capacities. In relation to this, the research carried out by Bayraktar (2011), Bertucci, Johnson, Johnson, and Conte (2011) and Prieto and Nistal (2009) claims that cooperative work improves interaction among them, adding that motivation obtained through cooperative work is greater than through other types of work, in tune with Johnson, Johnson, and Taylor (1993)'s findings on the promotion of group cohesion through cooperative work.

Moreover, significant differences exist based on teaching experience, with teachers who have less teaching experience showing a more positive attitude towards cooperative learning than teachers who have more teaching experience. This difference is observed mainly according to socialization and social interaction, the acquisition of habits of coexistence, responsibility and co-responsibility, and group enrichment through new ideas. In addition, teachers who have less teaching experience show a more positive attitude towards cooperative learning regarding whether it improves the students' tendency to help each other.

Thus, Cosgum (2016) says that experience is important and claims that practical experience helps student teachers in their teaching profession. Bayraktar (2011) and Goudas and Magotsiou (2009) agree with this because the result of their research shows cooperative learning improves the students' tendency to help each other and team work, while Bertucci et al. (2011), Prieto and Nistal (2009) and Gisbert (2008) show in their research that cooperative learning improves the interaction among students. Teachers who have from 1 to 5 years of experience have a more positive attitude towards cooperative learning regarding whether it promotes group cohesion compared to teachers who have from 6 to 10 years of experience. In their research, Johnson et al. (1993) claim cooperative learning improves group cohesion and the relationship with other students.

In conclusion, cooperative learning has increasingly been implemented in classes since it turned out to be a good tool for helping students to improve their academic achievement. For this reason, it is important that teachers become familiar with this method and show a positive attitude towards it. 


\section{References}

ANDRÉ, Amael; DENEUVE, Pascaleand LOUVET, Benoit. Cooperative learning in physical education and acceptance of students with learning disabilities. Journal of Applied Sport Psychology, Philadelphia, v. 23, n. 4, p. 474-485, 2011.

ANGUERA, Muhlise. Investigating the impacts of previous and current learning experiences on student teachers' teaching experiences. Educational Sciences, v. 16, n. 5, p. 1503-1530, 2016.

AUTONOMOUS REGION OF MADRID. Guía de centros docentes de la Comunidad de Madrid. Madrid: [s. n.], 2014. Available on: <www.madrid.org/centros_docentes/guia/index.html>. Access on: 05 oct. 2015.

BAYRAKTAR, Gökhan. The effect of cooperative learning on students' approach to general gymnastics course and academic achievements. Educational Research and Reviews, v. 6, n. 1, p. 62, 2011.

BERNER, Lemuel. Cooperative and collaborated learning: a program for improving the retention of minority students: Virginia: [s. n.], 2000.

BERTUCCI, Andrea et al. The effects of task and resource interdependence on achievement and social support: an exploratory study of Italian children. The Journal of Psychology, London, v. 145, n. 4, p. 343360, 2011.

BLATCHFORD, Peter et al. Toward a social pedagogy of classroom group work. International Journal of Educational Research, Sevilla, v. 39, n. 1, p. 153-172, 2003.

CEA D'ANCONA, María Ángeles. Metodología cuantitativa: estrategias y técnicas de investigación social: síntesis. [S. I.: s. n.], 1999. Available on: <http://www.trabajosocial.unlp.edu.ar/uploads/docs/metodologia cuantitativa_estrategias_y_tecnicas_de_investigacion_social__cea_d_ancona.pdf $>$. Access on: 05 oct. 2015.

CEA D’ANCONA, María Ángeles. Métodos de encuesta: teoría y práctica, errores y mejora: síntesis. [S. I.: S. n.], 2004.

DURAN GISBERT, David; MONEREO FONT, Carles. The impact of peer tutoring on the improvement of linguistic competence, self-concept as a writer and pedagogical satisfaction. School Psychology International, Miami, v. 29, n. 4, p. 481-499, 2008.

DYSON, Ben; CASEY, Ashley. Cooperative learning in physical education: a research based approach. [S. I.]: Routledge, 2012.

EROGLU, Cihan; UNLU, Huseyin. Self-efficacy: its effects on physical education teacher candidates' attitudes toward the teaching profession. Educational Sciences, v. 15, n. 1, p. 201-212, 2015.

GILLIES, Robyn M.; BOYLE, Michael. Teachers' reflections on cooperative learning: issues of implementation. Teaching and Teacher Education, Kingdom, v. 26, n. 4, p. 933-940, 2010. 
GONZÁLEZ-TIRADOS, Rosa María. Bases conceptuales en el proceso de investigación: Madrid: ICE de la Universidad Politécnica de Madrid, 2009.

GOUDAS, Marios; MAGOTSIOU, Evmorfia. The effects of a cooperative physical education program on students' social skills. Journal of Applied Sport Psychology, Philadelphia, v. 21, n. 3, p. 356-364, 2009.

GUERRA, Paula; HELENA Montenegro. Conocimiento pedagógico: explorando nuevas aproximaciones. Educação e Pesquisa, São Paulo, v. 43, n. 3, p. 663-680, 2017.

HEINEMANN, Klaus. Introducción a la metodología de la investigación empírica en las ciencias del deporte. Barcelona: Paidotribo, 2003.

INSTITUTE OF STATISTICS FROM THE AUTONOMOUS REGION OF MADRID. Demografía y población. Madrid: [s. n.], 2013. Available on: <http://www.madrid.org/iestadis>. Access on: 05 oct. 2015.

JOHNSON, David W.; JOHNSON, Roger T. Cooperative learning and traditional American values: an appreciation. NASSP Bulletin, v. 80, n. 579, p. 63-65, 1996.

JOHNSON, David W.; JOHNSON, Roger T. Learning together and alone: cooperative, competitive, and individualistic learning. [S. I.]: Prentice-Hall, 1987.

JOHNSON, David W.; JOHNSON, Roger T.; HOLUBEC, Edythe J. El aprendizaje cooperativo en el aula: Buenos Aires: Paidós, 1999.

JOHNSON, David W.; JOHNSON, Roger T.; TAYLOR, Barbara. Impact of cooperative and individualistic learning on high-ability students' achievement, self-esteem, and social acceptance. The Journal of Social Psychology, v. 133, n. 6, p. 839-844, 1993.

KAGAN, Shelly. Cooperative learning. San Clemente: CA Resources for Teachers, 1994.

LUSSIER, Robert N.; KIMBALL, David C. Applied sport management skills. United States: Human Kinetics: Champaign, 2008.

PERLMAN, Dana. Assisting preservice teachers toward more motivationally supportive instruction. Journal of Teaching in Physical Education, v. 34, n. 1, p. 119-130, 2015.

PRIETO, Jose Antonio; NISTAL, Paloma. Influencia del aprendizaje cooperativo en educación física. Revista Iberoamericana de Educación, Mexico, DF, v. 49, n. 4, p. 6-10, 2009.

PRIETO, Leonor. El aprendizaje cooperativo: Madrid: PPC, 2007.

RODRÍGUEZ OSUNA, Jacinto. La muestra: teoría y aplicación. In: GARCÍA FERRANDO, Manuel; IBÁÑEZ, Jesús; ALVIRA, Francisco (Comp.). El análisis de la realidad social: métodos y técnicas de investigación. 3. ed. Madrid: Alianza, 2002. p. 269-297. 
SABORIT, Jose Antonio et al. Teachers' Attitude and perception towards cooperative learning implementation: influence of continuing training. Teaching and Teacher Education, Kingdom, v. 59, p. 438-445, 2016.

SHOVAL, Ella; SHULRUF, Boaz. Who benefits from cooperative learning with movement activity? School Psychology International, Kingdom, v. 32, n. 1, p. 58-72, 2011.

TEWELDEBRHAN, Abraha Reda. Attitude of students towards cooperative learning methods (the case of Wolaita Sodo University Psychology Department second-year students). International Journal of Sciences, v. 24, n. 2, p. 33-44, 2015.

TRAVER, Joan Andrés; GARCÍA, Rafaela. Construcción de un cuestionario-escala sobre actitud del profesorado frente a la innovación educativa mediante técnicas de trabajo cooperativo (CAPIC). Revista Electrónica De Investigación Educativa, Mexico, DF, v. 9, n. 1, p. 1-14, 2007.

WALLHEAD, Tristan; DYSON, Ben. A didactic analysis of content development during cooperative learning in primary physical education. European Physical Education Review, Kingdom, v. 23, n. 3, p. 311-326, 2017.

Received on January 19th, 2018 Approved on September 25th, 2018.

María Fernández-Rivas holds a PhD in Physical Activity and Sport Sciences. She is the author of several related articles on Physical Education and Methodology. She has also participated as a researcher in several research projects. She works as a teacher at the Faculty of Human and Social Sciences, Universidad Pontificia de Comillas, Spain.

María Espada-Mateos holds a PhD in Physical Activity and Sport Sciences. She has participated as a researcher in several research projects. She is the author of several related articles on Physical Education and Sport Sciences. She works as a teacher and a researcher at the Faculty of Physical Activity and Sport Sciences, Universidad Politécnica de Madrid, Spain. 